\title{
DEFENSE GEOGRAPHY AND THE CHARACTER OF THE INDONESIAN TOTAL DEFENSE SYSTEM (SISHANTA)
}

\author{
Endro Tri Susdarwono \\ Universitas Peradaban
}

\begin{abstract}
Abstrak: Defense geography is a scientific study which is a branch of human geography. Starting from the implementation of military tactics, when reading topographic maps up to the implementation of military campaigns on a certain surface of the earth, so that how to determine and decide on defense policies and strategies always requires consideration of defense geography. In accordance with the defense system adopted by the Indonesian nation total defense system (Sishanta), namely a defense system mobilizes all national resources, both artificial resources and natural resources. That natural resources and space are geography or terrain to be used as much as possible to carry out total defense system (sishanta), in order to face threats, both of within and abroad. Introduction to defense geography, preferably in line with the preparation of the Defense Area Spatial Plan. Linkages between total defense system (sishanta) and Indonesia's geographic environment into consideration the urgency of the inclusion of defense geography in geography education in Indonesia.
\end{abstract}

Keywords: defense geography; geography education; total defense system (sishanta)

\begin{abstract}
Abstrak: Geografi pertahanan merupakan suatu kajian ilmiah yang merupakan salah satu cabang dari geografi manusia. Mulai dari penerapan taktik militer, saat membaca peta topografi hingga pelaksanaan kampanye militer di permukaan bumi tertentu, sehingga cara menentukan dan memutuskan kebijakan dan strategi pertahanan selalu memerlukan pertimbangan geografi pertahanan. Sesuai dengan sistem pertahanan yang dianut oleh sistem pertahanan total bangsa Indonesia (Sishanta), yaitu sistem pertahanan yang menggerakkan seluruh sumber daya nasional, baik sumber daya buatan maupun sumber daya alam. Bahwa sumber daya alam dan ruang angkasa merupakan geografi atau medan yang akan digunakan semaksimal mungkin untuk menyelenggarakan sistem pertahanan total (sishanta), guna menghadapi ancaman, baik di dalam maupun di luar negeri. Pengenalan geografi pertahanan, sebaiknya sejalan dengan penyusunan Rencana Tata Ruang Wilayah Pertahanan. Keterkaitan antara total defense system (sishanta) dan lingkungan geografis Indonesia menjadi pertimbangan urgensi masuknya geografi pertahanan dalam pendidikan geografi di Indonesia.
\end{abstract}

Kata kunci: geografi pertahanan; pendidikan geografi; sistem pertahanan total (sishanta)

\section{A. INTRODUCTION}

According to Bintarto, Geography is the study / study of the earth and everything on it, such as the population, flora, fauna, climate, air and all its interactions. According to the Seminar and Workshop of the Indonesian Geographical Association (SEMILOKA IGI) in 1989, Geography is the study of the similarities and differences of geosphere phenomena from the perspective of environmentalism and 
territoriality in the spatial context (Murtianto, 2008).

The propensity of geography specialization is increasingly prevalent (especially in Indonesia). Geography is no longer interpreted as integrative, covering both physical and human aspects. This resulted in a study by geographers concerning only material objects of geography. Not infrequently it would be overlapping with other science clusters (Aksa et al, 2019).

It is not unusual for many people who do not understand the branch of geography called defense geography, because in addition to the science of geography itself is only regarded as the study of the surface of the earth, then referred to as earth science. Though geography is not just a science that studies the surface of the earth but is wider than that, namely a science that studies the reciprocal relationship between geographic phenomena and the ecology that lives on the surface of the earth. Because of this relationship, geography consists of physical geography and social geography. Physical geography, a combination of physical and mathematical sciences, such as mapping, climate, geology, and others. Whereas social geography is a combination of political, social, cultural, historical and human sciences. The combination of knowledge about humans and the science of geography gave birth to what is called human geography.

Defense geography is a scientific study which is a branch of human geography. Developing and originating from military geography (eg Mauire, 1900) which wrote the idea of General Sherman in the Civil War (American Civil War) writing in 1844, titled "Every Day" which explains the importance of using Atlas - as "Geography", which included in Military Education material (Maguiere, 1900). then developed by O'Sulivan and Miller in a book entitled Geography of Warfare, which explains that "that the fundamental strategic and tactical problems are geographical in nature" (O 'Sulivan and Miller, 1983), namely that " the fundamental problem of tactics and strategy naturally is basically geography '. In the end, a book titled "Geography of Defense" was edited by Michael Bateman and Raymond Riley in 1987. The book essentially discusses how important geographic aspects or phenomena affect defense or war activities or the military.

Law No. 3 of 2002 concerning National Defense states that national defense is all efforts to defend the sovereignty of the country, the territorial integrity of the Unitary State of the Republic of Indonesia (NKRI), and the safety of all nations from all forms of threats and disturbances to the integrity of the nation and state. 
The main architect of the gerilyagovernment (total defense system) has been Colonel (now General) Abdul Haris Nasution. As commander of the Siliwangi division he had witnessed the failure of linear defence by his underequipped troops against the armoured columns of the Dutch forces during the first military action. Within a mereweeks his first and second lines were broken through and most cities and towns of West Java seized by the enemy. His division was broken down into tiny units, often commanders were looking for their subordinate troops and vice versa the troops were looking for their commander. But when the smoke of battle lifted during the relative quiet of a cease fire, it was found that the dispersed units had regrouped themselves in the hundreds of villages of west Java, consolidated themselves and had started to operate again. They formed what was then known under the term "isolated pockets" which the Dutch later demanded to be removed under the terms of the Renville agreement. And indeed the Siliwangi units did form pockets of resistance, but they were not isolated. From pocket to pocket there were lines of communication, so that in fact the Republic was functioning again outside the cities and towns occupied by the enemy. Republican local administration was functioning again with the military as backbone and the military survived because of the support of the people organized by the local administration.

After the Renville agreement, the Siliwangi units were withdrawn to the remaining Republican territory in Central Java and put into the reserve as Kesatuan Reserve Umum (KRU - general reserve unit) Z. there was a regrouping of the division and Nasution was promoted to become Vice Commander-in-Chief of the Mobile Military Forces, as General Soedirman's second in command. $\mathrm{He}$ was also chief of the operations staff of the Headquarters. It was in that capacity that Nasution began to formulate his ideas on what was then known under its English name "total people's defence" which was later Indonesianised as Pertahanan Rakyat Semesta or Perang Rakyat Semesta.

For the Indonesian people, the nature of national defense is all total defense efforts, whose implementation is based on awareness of the rights and obligations of all citizens and the belief in their own strength to maintain the survival of an independent and sovereign Indonesian nation and state. The objectives of national defense include, First, safeguarding state sovereignty, which includes efforts to safeguard the country's ideological and political system. Second, maintaining the integrity of the NKRI as a final decision that must be maintained and maintained. Third, guarantee the safety of the nation and 
protect citizens from all forms of threats.

(Defense White Paper, 2008).

So that understanding of defense geography is indispensable for all citizens related to the characteristics of the defense system adopted by Indonesia, this becomes an interesting discourse to include defense geography in geography education.

\section{B. METHOD}

The research specifications in this study use descriptive analytics, which describes the results of the study in accordance with the problems and objectives to be achieved and analyze them. Data analysis (analyzing), which describes the data in the form of sentences that are good and correct, so that it is easy to read and given meaning (interpreted) so that the results of data analysis facilitate inductive conclusions. Materials (data) from the results of the processing are analyzed qualitatively and then discussed. Based on the results of the discussion then conclusions were taken as answers to the problems studied.

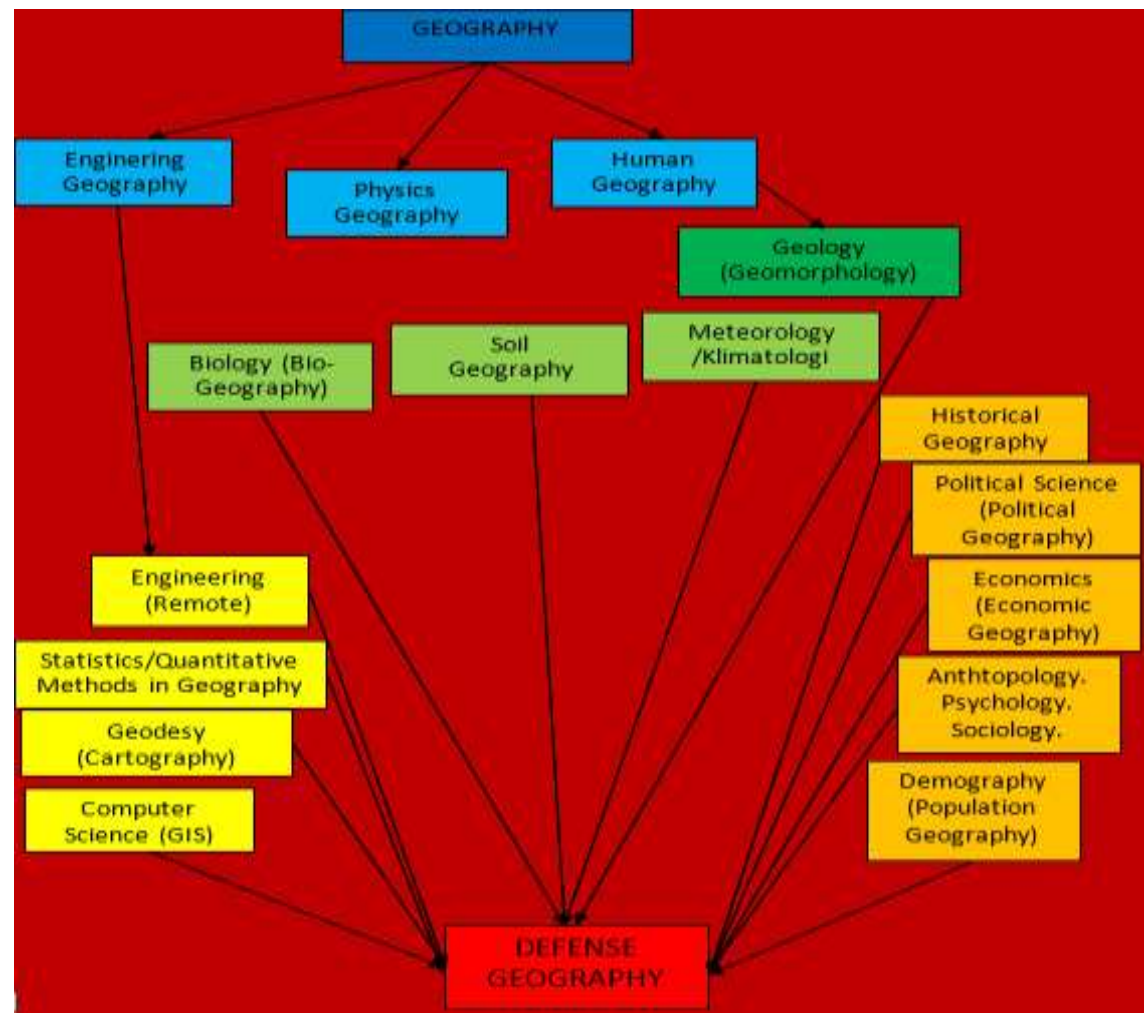

Figure. Geographic charts and branches of geography with defense geography

The basic objective of geography research is to improve better understanding of the necessity of location or place or spatial, especially to understand how or how varied the distribution of the phenomenon of the earth's surface, which interacts with the 
causes of similarities and / or differences between one place and location.

In other words, the main goal is to develop a sufficient understanding of the spatial interactions, to provide an opportunity for the realization of a comprehensive understanding of the entire surface of the earth and everything as an existing functioning system, and will be very influential towards the welfare or poverty of mankind on the surface of the earth. Basically, humans themselves are one of the geographic phenomena as well as being one of the studies of geography itself.

Geography itself has branches and subsidiary of geography itself, so it is very interesting how actually the contributions of branches and subsidiary of geography itself contribute to Defense Geography.

\section{RESULTS AND DISCUSSION \\ C.1. Defense and Geography}

There are several notions of "defense", first defense can be interpreted as an institution or organization, namely the ministry of defense; second, as an effort to manage various national resources that are intended in efforts to maintain the existence of a country, enforce state sovereignty, territorial integrity, and the safety of all nations and countries from all threats; third, defense can be interpreted as a defense stronghold to maintain a location, area, city, or capital of a particular country; and fourth, can also be interpreted as tactics and strategies in war or battle.

The first defense understanding as an organization is to have duties and functions, among others: in order to make defense policies and strategies and defense management policies. Whereas the second understanding, namely an effort to administer national defense, is carried out with the "national defense system - Sishaneg," which is a universal defense system that involves all citizens of the state, region and other national resources, and is prepared early by the government and held in total, integrated, directed, and continued. Whereas the executor of national defense is the main component consisting of the TNI, the reserve component, and the supporting component is national resources.

While defense, in the third and fourth terms, namely defense is viewed from a tactical and operational perspective, namely defense which is at the level of war and battle, or at the level of strategy, military operations and tactics. At this level, whether an army in a certain "location" - can be a city, village, city, or even the capital city - will carry out "defense operations", or will carry out "attack operations" against another location, "inhibitory operations," "Retaliatory attack" or carrying out "off involvement". Defense in this sense, as an operation planned by allocating various defense resources that exist in a 
location - a village, a township, a city, or a national capital - (defense management) - and its regional environment to maintain the existence and integrity of its defense area, and the safety of all citizens, property, personnel, and tools of war equipment contained in the territory that they maintain.

In addition, troops who survive in the defense stronghold, among others, must be able to destroy threats, attacks or enemy invasions, carry out counterattacks to teach and exploit the enemy, so that the enemy loses its intention or motivation to carry out attacks or survive, aka surrender. The implementation of defense operations is carried out using the principles or basics of defense by involving all the forces that exist in the surviving forces and all of the resources in the area that is defended.

While the purpose of defense in that context, is to develop favorable conditions, prevent the entry of enemies into an area, minimize enemy combat capabilities, trap and destroy the enemy, and save energy so that there is concentration elsewhere. In other words, defense operations have the purpose of getting "space" and "time" in order to continue attacks or counter attacks.

\section{C.2. Defense Geography}

Geography or commonly referred to as Earth Sciences, which is included in a family of sciences that examines all aspects of space from some natural symptoms and human symptoms on the surface of the earth. The surface of the earth consists of 3 (three) elements, namely the water layer, the soil layer, and the air layer. Geography pays attention to various natural, biological, social, and human symptoms on the surface of the earth and interrelates with each other's symptoms. Various natural symptoms, including for example patterns of the spread of climate, water, and soil. Various symptoms of society include, for example, villages, cities, countries, government, trade, and industry. These various symptoms are related and influence each other. Geography can be characterized as a comprehensive synthetic science, because it can be said to reach all events on the surface of the earth as a whole. Therefore, the reach of this field of knowledge is very broad in the local area to the region and even the whole world (Gie, 2001). Similarly, physiography, which is one of the branches of Geography which is included in Physical Geography, is the study of the development of the forms of the earth's surface, such as mountain ranges and oceanic curves that occur due to precipitation and dissolution which are very important for military tactics and strategies (Gie, 2001).

Defense Geography, has always had an influence on considering defense policies and strategies, every form of warfare and every force at the level of 
policy, strategy, operations and even tactics. These things will certainly always be overshadowed by changes in fields: politics, economy, social, science and technology, defense and security and other changes, especially terrorism, drug eradication, inter-state conflict, border disputes in land and sea with neighboring countries, or spoil over from conflicts between neighboring countries, horizontal conflicts, vulnerability to separatism, and other transnational crimes in the next two to three decades.

The basis of geography research's aim is to improve a better understanding of the location or location or spatial inevitability, especially to understand how or how the distribution of the phenomenon of the earth's surface, which interacts with the causes of similarities and / or differences between locations or locations another.

In other words, the main goal is to develop a sufficient understanding of the spatial interactions, to provide an opportunity for the realization of a comprehensive understanding of the entire surface of the earth and everything as an existing functioning system, and will be very influential towards the welfare or poverty of mankind on the surface of the earth. Basically, humans themselves are one of the geographic phenomena as well as being one of the studies of geography itself.
Geographical aspects of strategy or military are important factors. At present, there has been a growing Military Geography which is currently developing into Defense Geography. Different from the two terms, in addition to the mention of military geography and defense geography, also the scope of the discussion of defense geography is broader than military geography. Defense geography does not only cover the problems of tactics and military strategy, but also covers issues relating to defense policies and strategies, namely how does geography affect the purchase of primary weapons systems (defense equipment)? How does geography affect defense strategies? How does geography affect the title of defense? and various matters relating to defense aspects.

In essence, total defense efforts are defense models developed based on strategic considerations, not for reasons of inability to build modern defense forces. Although Indonesia has achieved a fairly high level of progress, the model will still be developed, by placing citizens as subjects of national defense according to their respective roles.

The most important book Nasution wrote during the period (between the end of 1952 to the end of 1955) most certainly was Pokok Pokok Perang Gerilya (Fundamentals of Guerilla Warfare). It was an elucidation of the concepts of guerilla warfare Nasution had planned 
and which had been implemented under his leadership in 1948-1949, and simultaneously a defense concept for Indonesia based on those experiences. The concepts formulated in this book later became the basis for the Indonesian defense doctrine which among other concepts was incorporated into the Doctrine of Territorial Warfare, and Territorial Command-the continuation of which is now under debate.

Law No. 3 of 2002 concerning National Defense states that the national defense system is a total defense system that involves all citizens of the state, region and other national resources, and is prepared early by the government and held in total, integrated, directed, and continue to uphold national sovereignty, territorial integrity and the safety of all nations from all threats (Law Number 3 of 2002 concerning National Defense, Article 1 paragraph 2). The defense system adopted by Indonesia is thus a total defense system that covers the concept of military defense and nonmilitary defense (Karim, 2014).

The total defense system is an improvement from the previous system, namely the total defense and security system (hankamrata). The total defense system itself was born from the postreform political conditions in 1998. The 2008 Defense White Paper states that equality implies the involvement of all people and as much as national resources, national facilities and infrastructure, as well as the entire territory as a whole (Defense White Papers, 2008).

Table. Geography Factors

\begin{tabular}{ll}
\hline Physical Factors & Cultural Factors \\
\hline Spatial Relationships & Racial and Etnic Roots \\
(Hubungan Spasial) & (Akar Ras dan Etnis) \\
Topography and Drainage & Population Patterns \\
(Topografi dan Drainase) & (Bentuk Populasi) \\
Geology and Soils & Social Structures \\
(Geologi dan Tanah) & (Struktur Sosial) \\
Vegetation & Languages and Religions \\
(Penumbuhan) & (Bahasa dan Agama) \\
Lautan, Pantai dan Selat & Industries and Land Use \\
(Oceans, Seashores and Straits) & (Industri dan Tata Guna Lahan) \\
Weather and Climate & Transportation Networks \\
(Cuaca dan Iklim) & (Jaringan Transportasi) \\
Daylight and Darkness & Telecommunication \\
(Cahaya siang dan Kegelapan) & (Telekomunikasi) \\
Gravity and Magnetism & Military Installations \\
(Gravitasi dan Magnet) & (Instalasi Militer) \\
\hline
\end{tabular}

Source: Collins, M.Jhon, Military Geography, Potomac Books, Inc, Washington, D.C. 1998, h. xix 
In accordance with the defense system adopted by the Indonesian people, the Total People's Defense System (Sishanrata) or the Total Defense System (Sishanta), namely a defense system that mobilizes all of its resources, consisting of Main components, Reserve components, and national resources, both artificial resources and natural resources. In line with the above, that natural resources and space are geography or terrain to be used as much as possible to carry out Sishanta in order to deal with threats, both those coming from within and from abroad.

The introduction of defense geography should be in line with the preparation of a defense Spatial Plan (RTRW). Because in the Defense RTRW it will contain the function or designation of the defense area, which consists of a static and dynamic Defense RTRW. Static Defense RTR includes location for

a. Base and / or knight;

b. Regional military training; military installation;

c. Air defense interests include: restricted areas (restricted areas), prohibited areas and danger areas as well as air defense identification zone (ADIZ);

d. Regional testing of military equipment and weapons;

e. Storage areas for explosive and other dangerous goods; f. Ammunition disposal areas and other dangerous defense equipment;

g. Strategic national vital objects; and / or other defense assets.

Whereas the dynamic RTRW of Defense includes locations for: military training areas; the resistance field;

a. The main defense field;

b. Area of resistance; battle area;

c. The area of communication of a mandala war;

d. The back area of a war mandala; and

e. Area of resistance.

To determine the function of the location of each RTRW mentioned above, knowledge of defense geography is needed, which is the suitability of the geographic environment for the Static Defense RTRW? And what about Dynamic? Geographical indicators are needed in determining the locations of these static and dynamic defenses. So determining the location or position according to the RTRW is not careless.

\section{CONCLUSIONS}

In various universities that have Geography majors, no one provides Defense Geography material, it is realized that the curriculum for the Geography Department is very broad and there is not enough time to study this material. Likewise at the Indonesian Defense University, which is the focal point of defense, there is no study 
program or defense geography course, even though all officers are aware of Indonesia's geography, Sishanta, and Territorial Development, as well as the RTRW, all requiring Geography and defense geography.

Of course something is misleading if it is suggested to ignore the contribution of geography to the military or war. But in geography itself there are branches and branches of geography itself, so it is very interesting how the contributions of branches and subsidiary of geography itself contribute to Defense Geography.

Indonesia, in addition to being geopolitical and geostrategic is an archipelago state which has a large and small number of 17,504 with a vast coastline and sea, its existence must be maintained, among others, against military and non-military threats. Thus, such geographical conditions will affect national defense policies and strategies. These defense policies and strategies will be elaborated by the formulation of the defense spatial plan. In conclusion, geography is very important and closely related to the military or defense, starting from the tactical level, strategy, and defense or military policy.

\section{REFERENCES}

Afandi, Widoyo, 2001, Epistemologi Geografi, Gadjah Mada University Press, Yogyakarta.
Aksa, Furqan Ishak et al, 2019, Geografi dalam Perspektif Filsafat Ilmu, Jurnal Majalah Geografi Indonesia, 33(1), 43-47.

Bakrie, Connie Rahakundini, 2007, Pertahanan Negara dan Postur TNI Ideal. Yayasan Obor Indonesia, Jakarta.

Buku Putih Indonesia 2005-2025 Tentang Penelitian, Pengembangan dan Penerapan Ilmu Pengetahuan dan Teknologi Bidang Pertahanan dan Keamanan Tahun 2006 Kementerian Negara Riset dan Teknologi Republik Indonesia.

Buku Putih Pertahanan Indonesia Tahun 2008 Departemen Pertahanan Republik Indonesia.

Buku Putih Pertahanan Indonesia Tahun 2015 Kementerian Pertahanan Republik Indonesia

Buku Putih Pertahanan Negara Republik Indonesia Tahun 2003 Kementerian Pertahanan

Gie, The liang dan Andrian The, 2001, Ensiklopedi Ilmu-Ilmu, Gadjah Mada University Press, Yogyakarta.

Karim, Silmy, 2014, Membangun Kemandirian Industri Pertahanan Indonesia. Kepustakaan Populer Gramedia, Jakarta.

Murtianto, Hendro, 2008, Modul Belajar Geografi. Universitas Pendidikan Indonesia, Bandung.

Sejarah Militer Kodam Vi Siliwangi, Siliwangi dari masa ke masa, Jakarta

Supriyatno, Makmur, 2014, Tentang Ilmu Pertahanan. Yayasan Pustaka Obor Indonesia, Jakarta. 